\title{
PACAP and PAC1 Receptor Expression in Human Insulinomas
}

\author{
Sandor Ferencz ${ }^{1} \cdot$ Denes Toth $^{2} \cdot$ Balint Kaszas $^{3} \cdot$ Sebastian Bardosi $^{4} \cdot$ Viktoria Vicena $^{5} \cdot$ Oszkar Karadi ${ }^{6}$. \\ Dora Reglodi $^{5}$. Dezso Kelemen ${ }^{1}$
}

Accepted: 20 March 2021 / Published online: 9 April 2021

(c) The Author(s) 2021

\begin{abstract}
Pituitary adenylate cyclase activating polypeptide (PACAP) is a neuropeptide with widespread occurrence and diverse functions. PACAP binds to specific PAC1 and non-specific VPAC1/2 receptors. PACAP is considered as a growth factor, as it plays important roles during development and participates in reparative processes. Highest concentrations are found in the nervous system and endocrine glands, where several functions are known, including actions in tissue growth, differentiation and tumour development. Therefore, we have investigated expression of PACAP and its receptors in different tumours, including those of endocrine glands. We showed earlier that PACAP and PAC1 receptor staining intensity decreased in pancreatic ductal adenocarcinoma. In the present study we aimed to investigate alterations of PACAP and PAC1 receptor in human insulinoma and compared the immunostaining pattern with samples from chronic pancreatitis patients. We collected perioperative and histological data of patients who underwent operation because of insulinoma or chronic pancreatitis over a five-year-long period. Histology showed chronic pancreatitis with severe scar formation in pancreatitis patients, while tumour samples evidenced Grade 1 or 2 insulinoma. PACAP and PAC1 receptor expression was studied using immunohistochemistry. Staining intensity was very strong in the Langerhans islets of normal tissue and discernible staining was also observed in the exocrine pancreas. Immunostaining intensity for both PACAP and PAC1 receptor was markedly weaker in insulinoma samples, and disappeared from chronic pancreatitis samples except for intact islets. These findings show that PAC1 receptor/PACAP signalling is altered in insulinoma and this suggests a possible involvement of this system in tumour growth or differentiation.
\end{abstract}

Keywords PACAP $\cdot \mathrm{PAC} 1$ receptor $\cdot$ Insulinoma $\cdot$ Pancreas $\cdot$ Chronic pancreatitis

\author{
Sandor Ferencz and Denes Toth as well as Dora Reglodi and \\ Dezso Kelemen made equal contribution, as shared first authors \\ and shared last authors, respectively.

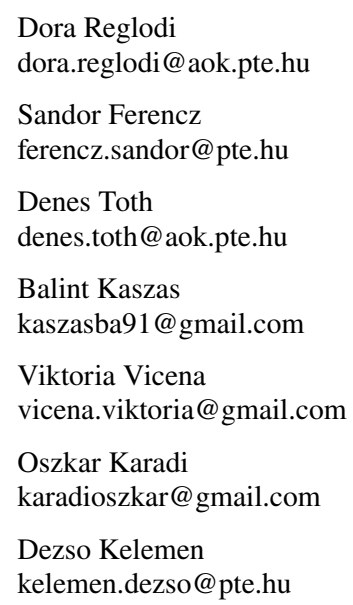 \\ 1 Department of Surgery, University of Pécs Medical School, \\ Ifjúság útja 13, Pécs 7624, Hungary \\ 2 Department of Forensic Medicine, University of Pécs \\ Medical School, Szigeti út 12, Pécs 7624, Hungary \\ 3 Department of Pathology, University of Pécs Medical School, \\ Szigeti út 12, Pécs 7624, Hungary \\ 4 Center for Histology, Cytology and Molecular Diagnostics, \\ and Proteopath GmbH, 54296 Trier, Germany \\ 5 Department of Anatomy, MTA-PTE PACAP Research \\ Group, University of Pécs Medical School, Szigeti út 12, \\ Pécs 7624, Hungary \\ 6 Department of Oncology, University of Pécs Medical School, \\ Édesanyák útja 17, Pécs 7624, Hungary
}




\section{Introduction}

Both benign and malignant pancreas diseases are frequent. Adenocarcinoma of the pancreas is among the most malignant tumours, while acute and chronic pancreatitis affect a large population all around the world. Insulinoma is a benign, rare tumour type, many times with complicated diagnosis and therapy. Chronic pancreatitis is associated with repeated inflammations, causing tissue fibrosis, often pain and destruction of the pancreas. It affects both the endocrine and the exocrine parts of the organ, with need for specific nutrition and diet (Gress et al. 1994a, b; Michalski et al. 2008; Wiese et al. 2020). Epidemiological data are difficult to estimate (incidence is varying from 4 to $13.4 / 100.000$ ), because patients have often compliance problems as chronic alcoholism is one of the leading causes of this disease (Lévy et al. 2014). It is known that patients with chronic pancreatitis have 13.3 times higher risk for pancreas malignancy than healthy people (Raimondi et al. 2010). Some symptoms of chronic pancreatitis and pancreas carcinoma are similar and because of the non-specific symptoms correct diagnosis and definite decision is difficult to make. Based on these facts, severe chronic pancreatitis and suspect tumour onset represent operative indication.

Insulinoma is a rare insulin-producing neuroendocrine tumour. It is the most common cause of hypoglycaemia associated with endogenous high level of insulin, in some cases associated with MEN-1 (multiple endocrine neoplasia) syndrome (Shin et al. 2010). The obligatory diagnostic triad (Whipple's triad) for insulinoma are fasting provoked hypoglycaemia, blood glucose level under $50 \mathrm{mg} / \mathrm{dl}$ at the onset of symptoms, and the decrease of symptoms after glucose administration (Whipple and Frantz 1935). The incidence of insulinoma is generally about $0.4 \%$ and $1-4 / 1,000,000$ of the population is affected (Mehrabi et al. 2014; Shin et al. 2010). Most insulinomas are benign, solitary, and surgical resection ensure complete resolution of the illness. Enucleation is the appropriate solution in most cases, but rarely, such as in case of malignant insulinoma, pancreas resection or cytoreductive surgery is also recommended. Simultaneous oncotherapy is frequently needed in these severe cases. In the 1950's administration of diazoxide was widely used. This antihypertensive agent, used orally, inhibits insulin release from the $\beta$-cells by $\alpha$-adrenergic receptor stimulation. Mild and tolerable side effects, such as fluid retention, nausea, hirsutism, made the use of this drug complicated (Gill et al. 1997; Goode et al. 1986). New approach shows the use of longacting somatostatin analogues (octreotide), which decrease plasma insulin concentration (Maton 1993). Octreotide can produce side effects similar to those in somatostatinoma: diabetes, cholelithiasis, weight loss. The goal of the drug administration in advanced cases is to lengthen time until surgery or patient palliation in incurable cases (Burns and Edil 2012; Okabayashi et al. 2013; Shin et al. 2010).

Pituitary adenylate cyclase activating polypeptide (PACAP) is a 27- or 38-amino acid neuropeptide, first isolated as a hypothalamic neuropeptide acting on the pituitary cAMP release (Hirabayashi et al. 2018; Miyata et al. 1989). PACAP has two forms: one has 38 amino acid residues (PACAP38), while the shorter form has 27 amino acids (PACAP27) (Miyata et al. 1990). Several former studies proved that PACAP can be found in the entire body, with the highest concentrations in the central nervous system and endocrine glands, but it is also present in the digestive, cardiovascular, and urogenital systems (Elsas et al. 1996; Lajko et al. 2018; Ojala et al. 2019; Parsons and May 2019; Reglodi et al. 2018; Sarszegi et al. 2019; Reglodi and Tamas 2016; Vaudry et al. 2009). The neuropeptide has diverse functions by binding to specific PAC1, and non-specific VPAC1 and VPAC2 receptors. Among others, the effects of PACAP have been shown in the Schwann cells, retina, cornea, smooth muscle contractility, neuronal excitability and fertility (Maugeri et al. 2019a; b, c; May et al. 2021; Shan et al. 2021). The VPAC receptors bind the homologous VIP peptide (vasoactive intestinal peptide) with equal affinity, while PAC1 is specific for PACAP (Girard et al. 2020; Reglodi et al. 2018; Rytel et al. 2020; Vaudry et al. 2009). PACAP and PACAP receptors have been detected in various exocrine glands: there are numerous PACAP-ergic fibers in the lacrimal gland (Elsas et al. 1996) and PAC1 receptors are involved in stimulation of tear secretion (Gaál et al. 2008; Nakamachi et al. 2016). PACAP-ergic nerves and PACAP receptors have also been described in the mammary and salivary glands (Czegledi et al. 2011; Pedersen et al. 2000; Pohóczky et al. 2020; Skakkebaek et al. 1999; Tobin et al. 1995). In the salivary glands, PACAP stimulates secretion (Matoba et al. 2016) and increases protein production (Calvert et al. 1998; Kamaishi et al. 2004; Mirfendereski et al. 1997). PACAP has also been described in the exocrine pancreas, which is analogous to a serous salivary gland in structure (Schmidt et al. 1993). The endocrine part of the pancreas, containing the islets of Langerhans, expresses markedly high levels of PACAP, similarly to other endocrine glands (Ferencz et al. 2019). The intrapancreatic PACAP has an important effect in the regulation of beta cell proliferation (Sakurai et al. 2011) and it plays an important regulatory role in both insulin and glucagon secretion. In vitro and in vivo studies have shown that PACAP increases insulin outflow after glucose stimulation in mouse and human models. Both subtypes elevate insulin secretion on isolated islets and perfused pancreas, where the stimulating potential of PACAP27 and PACAP38 is equal (Fridolf et al. 1992; Klinteberg et al. 1996; Yada et al. 1994). It has been shown 
that PACAP38 stimulates insulin secretion glucose- and dose-dependently via the PAC1 receptor, not by VPAC1 or VPAC2 receptors (Liu et al. 2019). It has also been proven that PAC1 and VPAC2 receptor deletion can cause glucose intolerance, influencing mediation of prandial insulin secretion and glucagon response to hypoglycaemia (Winzell and Ahrén 2007).

Numerous studies have described changes of PACAP and PACAP receptors expression in pathological conditions, including pancreas diseases. In a mouse model of pancreatitis induced by cerulein, increased pancreatic expression of PACAP could be observed (Hamagami et al. 2009). PACAP, along with its receptors, is involved in cell proliferation and differentiation, as well as tumour transformation (Jung et al. 2011; Moody et al. 2003, 2016; Moody and Jensen 2016; Schulz et al. 2004, 2015). PACAP can function as a growth factor for some tumour cells (Moody et al. 2003), while it inhibits growth of others (Wojcieszak and Zawilska 2014). PACAP increases tumour proliferation on AR4-2 J rat pancreatic carcinoma cell line (Schäfer et al. 1996). PACAP and PAC1 receptor expression can be altered in several types of tumours such as thyroid papillary carcinoma or testis cancer (Bardosi et al. 2016; Nakamura et al. 2014). Previous findings have shown messenger RNA of PAC1, VPAC1 and VPAC2 in insulinoma cells (Borboni et al. 1999). It is also known that PACAP inhibits pancreas islet mass expansion and pancreatic islet density, which is associated with islet neogenesis in type II diabetes (Inoue et al. 2013). In our recent study, we investigated histological samples from pancreas ductal adenocarcinoma patients. The staining intensity of PAC1 receptor was strong in normal tissues of pancreas, but it was much weaker in the adenocarcinoma. We found a very high level of immunostaining of PACAP in islets and nerves in tumour-free parts and very weak intensity in the exocrine parts. In the carcinoma samples there was no PACAP immunostaining. We supposed that the lack of PAC1 receptor/PACAP signalling could have an impact on growth and differentiation of pancreas adenocarcinoma (Ferencz et al. 2019). However, it is not known how expression of PACAP and its specific receptor change in pancreas insulinoma. Therefore, the aim of the present study was to investigate whether there is a change in the expression of PACAP and PAC1 receptor in insulinoma and we used samples from chronic pancreatitis patients for comparison.

\section{Materials and Methods}

\section{Data Collection of the Patients}

A 5-year-long period (January 2014-August 2018) was investigated. Pre- and perioperative patient data were collected. All patients were operated in our Department of
Surgery because of either chronic pancreatitis, suspected pancreas tumour, or insulinoma proven with fine needle aspiration biopsy. Operation type, as well as histological findings, grading, and margin resection were investigated (ethical permission number: PTE/83069/2018).

\section{Histology and Immunohistology}

Following complete patient data collecting new histological sections were made and prepared for further specific histological examination of PACAP and PAC1 receptor expression. Immunohistochemical staining was performed on 2 - $\mu \mathrm{m}$-thick paraffin sections fixed in $4 \%$ buffered formalin. Sections were stained with human anti-PACAP38 antibody (Peninsula, CA, USA, dilution of 1:200) and human PAC1 receptor antibody raised in rabbit (Sigma-Aldrich, Budapest, Hungary, dilution of 1:200), following standard immunohistochemical procedures. Staining was performed with EnVision FLEX Visualization Systems for Dako Omins (Dako, Denmark), similarly to earlier descriptions (Ferencz et al. 2019; Nakamura et al. 2014). As a chromogen for the immunohistochemical staining, liquid fast-red substrate kit (Abcam, UK) was used. Pathological analysis was done by expert pathologists. By omitting the primary antiserum, a method control was performed, which resulted in no staining. Tumour cell staining intensity was compared to that of tumour-free tissue in the same pancreas tissue in a semiquantitative way.

\section{Results}

\section{Clinical Data}

In chronic pancreatitis patients, the histological samples of thirty patients ( 23 males and 7 females, in the age of 30 to 75 years; mean age 56,8 years) were collected. Frey operation was performed in twenty cases, pancreatoduodenectomy in five cases, and cystojejunostomy in the other five cases. Data of five patients with insulinoma ( 3 males, 2 females, in the age of 26 to 50 years; mean age 40,6 years) were investigated. Enucleation of insulinoma was performed in three patients, in case of 1 patient distal pancreas resection and splenectomy, by another patient conventional Whipple operation was chosen. Except for patients undergoing only enucleation, all other patients were transferred to the Intensive Care Unit (ICU) for a routine postoperative observation. No complication appeared; all patients were emitted 8-14 days after surgery.

The histological results showed advanced chronic pancreatitis with severe scar formation in all chronic pancreatitis patients, there was no sign for malignancy. Histological examination of insulinoma cases showed Grade 1 insulinoma 
in four patients, and Grade 2 in one patient. Tumour staging in three cases was pT1, in two cases pT2. Lymph node staging was N0 in two cases (Whipple operation and distal pancreas resection), the other specimens (enucleation) contained no lymph nodes. Resection margin was not affected (R0 resection) in three cases and samples from two patients showed affected resection margin (R1 resection), without perineural, perivascular invasion.

\section{Histology and Immunohistology}

In accordance with our earlier observations (Ferencz et al. 2019), strong PACAP and PAC1 receptor immunohistochemical staining was detected in the Langerhans islets of normal pancreatic tissue and discernible staining could be observed in the exocrine pancreas (Figs. 1, 2). Insulinoma cells showed positivity for both PACAP and PAC1 receptor, however, the expression of PACAP and its receptor was markedly weaker than in normal islets (Fig. 2b).

In chronic pancreatitis the loss of exocrine structures with relative sparing of islets, fibrosis and signs of chronic inflammation could be detected with preserved strong PACAP and PAC1 receptor staining in the islets and without PACAP or PAC1 receptor staining in the area of chronic inflammation (Fig. 3). Thus, our results show that PACAP and PAC1

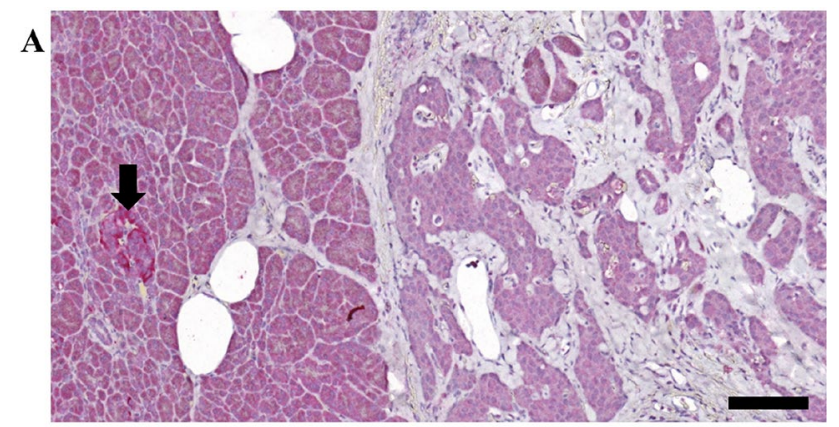

$\mathbf{B}$

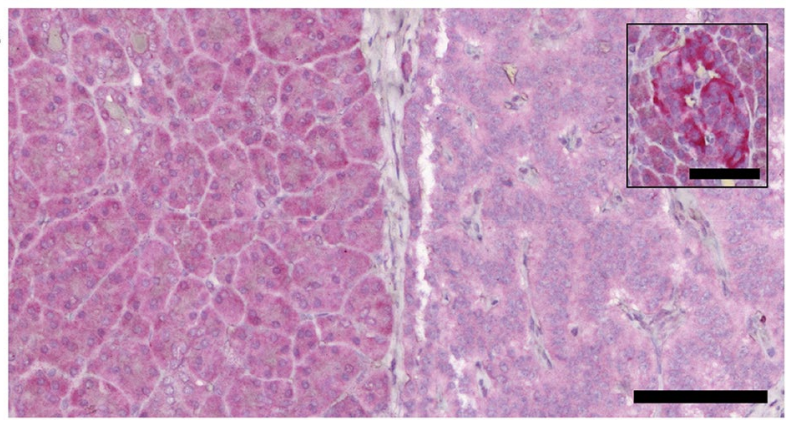

Fig. 1 PACAP immunostaining in normal pancreas and insulinomas. Scale bar: $100 \mu \mathrm{m}$ (in insert $50 \mu \mathrm{m}$ ). Normal, strong PACAP staining was present in the healthy islets (arrow in $\mathbf{a}$ and insert picture of $\mathbf{b}$ ). The normal exocrine part showed mild staining intensity (left side of $\mathbf{a}$ and $\mathbf{b}$ ), while in case of the insulinoma cells (right side of $\mathbf{a}$ and $\mathbf{b}$ ) a weak staining could be observed. In picture $\mathbf{b}$ the staining intensity of the insulinoma cells can be compared with a healthy islet (insert)
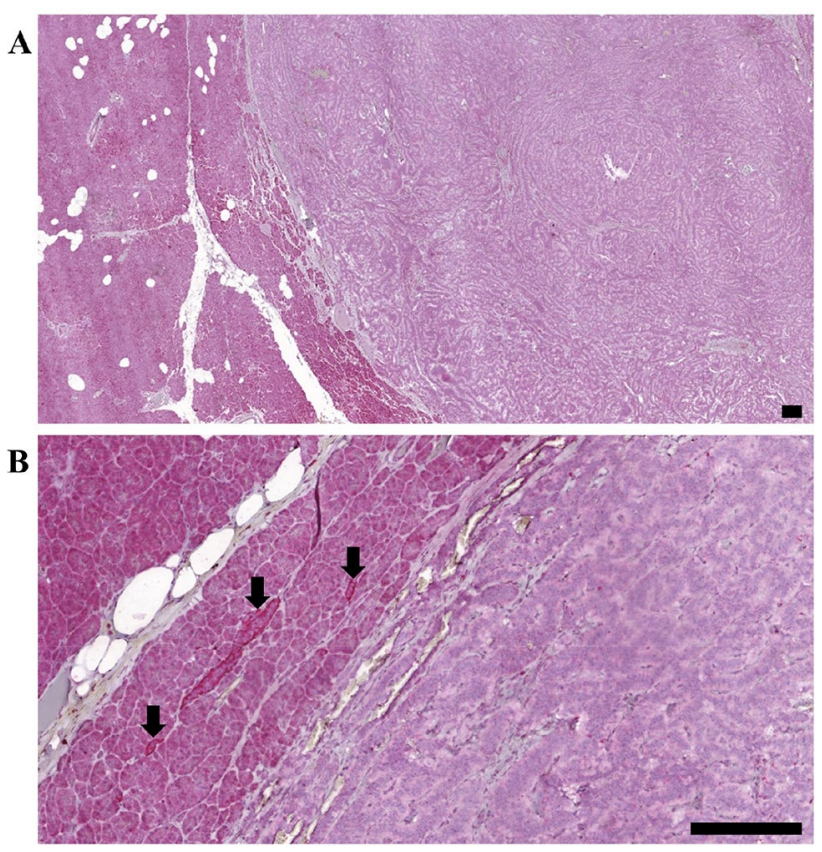

Fig. 2 PAC1 receptor immunostaining in normal pancreas and insulinomas. Scale bar: $200 \mu \mathrm{m}$. Normal, strong PAC1 receptor staining in the healthy islets (arrows in b) and mild staining intensity of the normal exocrine part (left side of $\mathbf{a}$ and $\mathbf{b}$ ) could be detected. The tumour cells (right side of $\mathbf{a}$ and $\mathbf{b}$ ) showed very weak staining

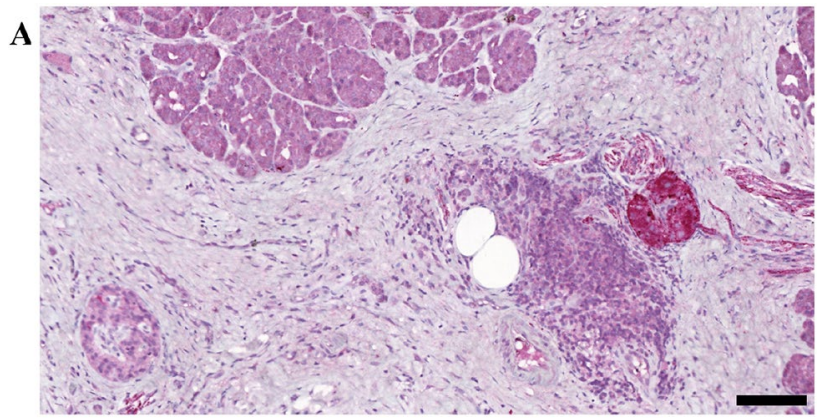

B

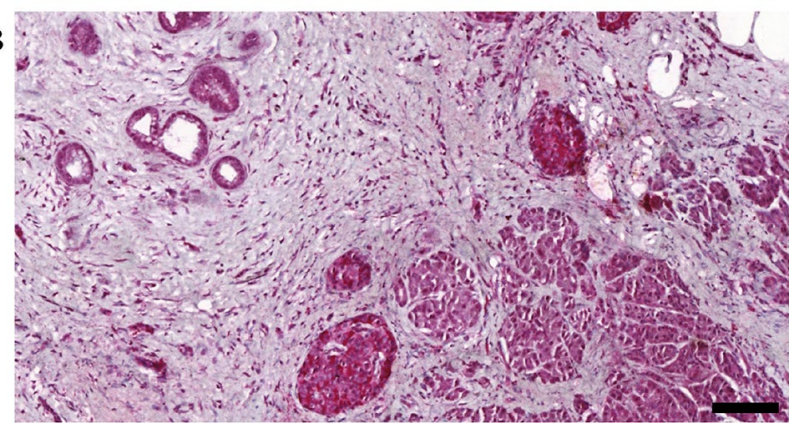

Fig. 3 PACAP (a) and PAC1 receptor (b) immunohistochemistry in chronic pancreatitis. Scale bar: $100 \mu \mathrm{m}$. Normal, strong PACAP and PAC1 receptor staining intensity could be observed in the islets. The exocrine part showed histological signs of chronic inflammation without specific immunostaining pattern 
receptor-like immunoreactivity is strongly reduced in insulinomas compared to normal islets.

\section{Discussion}

In our study we analysed normal pancreas, chronic pancreatitis and insulinoma samples for PACAP and PAC1 receptor immunostaining. We found a decreased or diminished peptide and receptor expression in the insulinoma parts compared to the normal tissue. This finding is similar to our earlier observation in pancreatic ductal adenocarcinoma, where we also found diminished expression of PACAP and PAC1 receptor in the adenocarcinoma parts compared to normal exocrine acini. Although these two tumours are completely different in development, malignancy and cell type, the expression pattern of the peptide and its receptor changed in a similar way.

PACAP is known to be involved in the growth and differentiation of various tumour types. The participation of PACAP in tumour growth is varying depending on the cell type, differentiation stage of the tumour and PACAP concentration. Thus, while PACAP stimulates growth of some tumour cells due to its antiapoptotic actions, it inhibits proliferation of other tumour cell types and was even found to inhibit migration of malignant cells (Moody et al. 2020; Toth et al. 2020). Several environmental circumstances also influence the exact effect of PACAP. For example, PACAP, by itself, had no effect on the proliferation or survival of JAR choriocarcinoma cells, but enhanced the cell death promoting effect of oxidative stress (Boronkai et al. 2009). Less is known about the actions of PACAP in benign tumour cells and little is known about PACAP and its receptors also in endocrine tumours. As PACAP is very strongly expressed in endocrine glands, attention should be focused on endocrine tumours. Some data are available, but this field lacks systematic investigation. For example, PACAP has been shown to induce vascular endothelial growth factor production and activate voltage-gated sodium channels in pituitary adenoma (Koshimura et al. 1997; Lohrer et al. 2001), but it inhibits apoptosis in another human pituitary adenoma cell line (Oka et al. 1999). PACAP is found in the majority of human pheochromocytoma cases, and these cells are also often used in studying mechanisms of PACAP (Inoue et al. 2020; Thouënnon et al. 2010). Altered PACAP and PAC1 receptor expression has also been described in thyroid tumours (Bardosi et al. 2016).

Our findings in insulinomas are in contrast to what we had expected. Both PACAP and its closely related peptide, VIP, are strongly expressed in the endocrine cells of the insula, we expected that a cell proliferation from these cells would also show strong expression. Other studies in VIPomas strengthened this hypothesis, as strong VIP and
VPAC receptor expression was described in a VIPoma case (Nakayama et al. 2009). Similar to our present findings, a decrease in immunosignal for PACAP was also observed in parathyroid adenomas (Luts et al. 1996).

It is well known that numerous growth factors play an important role in pancreatic organogenesis and are connected with some pathological disorders. The pro-inflammatory cytokines interleukin-1-beta and interferon-gamma elevate mitochondrial superoxide levels leading to beta cell failure and loss of insulin-producing cells in vitro (Barlow et al. 2018). Fibroblast growth factor (FGF) is involved in regulation of tumour growth and differentiation, but on the other hand FGF is also known to refine insulin sensitivity in obese animal models (Xu et al. 2017). Transforming growth factor beta's important role in tumour growth is well documented and it also stimulates pancreatic islet cells (Sayo et al. 2000). Previous studies showed that high expression of nerve growth factor (NGF) in the pancreas is associated with increased inflammatory response and more severe pain (Saloman et al. 2018). Studies showed that both the insulin and NGF immunofluorescent labelling was weaker in insulinoma samples (Vidaltamayo et al. 2003). Epidermal growth factor (EGF) appears in pancreatic ductal adenocarcinomas, and an in vitro study showed increase in level of JNK after administration of EGF, vitronectin and fibronectin in insulinoma cells (Kacar and Bolkent 2019).

The diagnosis and follow-up of prognosis is difficult in cases of variable malignancies, as well as neuroendocrine tumours, the available biomarkers at present have mild sensitivity and specificity. Nowadays precise, personalized treatment approaches, reliable prognostic, and treatment -predictive biomarkers are needed (Le et al. 2016; Loosen et al. 2017; Yamaoka et al. 2017). Although neuroendocrine tumours of the pancreas are rare malignancies, most of them are part of hereditary syndromes, with increased need for good diagnostic markers. In cases of pancreatic neuroendocrine tumours (PNETs) Chromogranin A $(\mathrm{Cg}$ A) seems to be a reliable serum diagnostic marker, but it is proven that $\mathrm{Cg} \mathrm{A}$ is not sensitive and specific enough in insulinoma patients (Qiao et al. 2014). There is a trend for combination of biomarkers (e.g. neurone specific enolase, pancreatic polypeptide) with $\mathrm{Cg}$ A (Bocchini et al. 2020; Chen et al. 2019). The neuropeptide PACAP has an important role in the development of nervous system and of peripheral organs (Fulop et al. 2019; Sandor et al. 2016; $\mathrm{Xu}$ et al. 2016). Based on this fact, it is not suprising that some of the tumours can express alterations in PACAP and/ or receptors. Some tumour types show overexpression, while others show decrease in PACAP-ergic signalling. In vitro studies proved the stimulating or inhibiting effect of PACAP on tumour growth, depending on some factors like tumour type, differentiation level, origin of the tumour or its environment (Zibara et al. 2018). For example, PACAP can 
decrease cell survival on retinoblastoma cells (Wojcieszak and Zawilska 2014), leads to milder invasive ability of glioblastoma cells (Maugeri et al. 2016), induces neuroblastoma differentiation into benign form (Maugeri et al. 2018) and inhibits tumour growth in cervix carcinoma (Lee et al. 2014). In contrast, PACAP can induce proliferation of an osteosarcoma cell line (Juhász et al. 2014) and the number of viable cells increases in some colon tumour cell lines (Le et al. 2002). Alternating effects can even be observed on the same cell line, depending on the length of exposure and the peptide concentration. For example, short exposure to PACAP increases cell proliferation, while long exposure inhibits it in a prostate cancer cell line (Farini et al. 2003). Nanomolar concentration of PACAP shows no effect on cell survival in case of a human retinoblastoma cell line, but increasing concentrations decrease cell survival (Wojcieszak and Zawilska 2014). As PACAP/VIP receptor family may have strong effects in tumour genesis, these receptors are frequently expressed in the most common human tumours, like prostate, breast, pancreatic ductal carcinoma, small cell lung cancer, colon adenocarcinoma, stomach, liver, urinary bladder, meningioma and lymphomas. The receptor type is predominantly VPAC1 in these cases. Leiomyomas express VPAC2 receptors, whereas endometrium carcinoma, paraganglioma, or the pheochromocytoma mainly express PAC1 receptors (Reubi et al. 2000). Previous examinations proved that VIP/PACAP-receptor expression is present in only $65 \%$ of pancreatic ductal carcinomas, and VPAC1 and VPAC2 receptors were found in pancreatic tumour samples (Moody et al. 2016). This type of receptor overexpression (Hessenius et al. 2000) urged the clinical use of radiolabelled VIP-analogues in various cancer types, including pancreas adenocarcinoma, VIPoma, and somatostatin analogues on neuroendocrine tumours (Moody et al. 2016; Raderer et al. 1998; Tang et al. 1997). Based on the observation of Hessenius and co-workers (Hessenius et al. 2000), no imaging was seen with radiolabelled VIP-analogues in pancreatic cancer patients, and in vitro binding studies showed no overexpression of VPAC1 receptor in cases of these tumour types. Former studies examined PACAP expression in some tumours using radioimmunoassay and immunohistochemistry (Tamas et al. 2016). In our earlier studies, we found PAC1 receptor expression in the exocrine part of pancreas almost in all cases of normal pancreas tissue, but markedly low expression in the adenocarcinoma parts (Ferencz et al. 2019), similarly to findings in lung, kidney and colon cancer samples, where lower PACAP tissue level was found in contrast to the elevated levels in prostatic cancer (Szanto et al. 2012; Tamas et al. 2016). An altered staining pattern was observed in different human testicular cancers (Nakamura et al. 2014) and in human thyroid papillary carcinoma (Bardosi et al. 2016).
In this study we found a weak PACAP expression in the normal exocrine pancreas, with very strong immunolabelling in the islets. Insulinoma samples showed markedly weaker staining compared to normal controls. Although our study involved a small number of patients, and it is not clear at this point what the consequences of the reduction of PACAP and PAC1 receptor expression are, these findings suggest a possible involvement of this system in tumour growth.

Acknowledgements This study was funded by: GINOP-2.3.2-152016-00050 "PEPSYS", MTA-TKI14016; NKFIH K119759,K135457; Bolyai Scholarship, EFOP-3.6.3-00009, EFOP-3.6.1.-16-2016-00004 Comprehensive Development for Implementing Smart Specialization Strategies at the University of Pécs; New Excellence Program, UNKP-16-4-IV, TAMOP 4.2.4.A/2-11-1-2012-0001, EFOP-3.6.2-162017-00008, "The role of neuro-inflammation in neurodegeneration: from molecules to clinics". Higher Education Institutional Excellence Programme of the Ministry of Human Capacities in Hungary, within the framework of the 20765-3/2018/FEKUTSTRAT; NAP2017-1.2.1NKP-2017-00002;FIKPIII. Project no. TKP2020-IKA-08 has been implemented with the support provided from the National Research, Development and Innovation Fund of Hungary, financed under the 2020-4.1.1-TKP2020 funding scheme.

Author Contributions SF and DR designed the whole study. RD and DK supervised the whole project. SF, VV, BK and OK collected patient data. SF, BK, VV and DT performed data analysis. SB performed histological examination. SF and RD drafted the manuscript. All authors critically revised the article and approved the final manuscript.

Funding Open access funding provided by University of Pécs.

Data Availability The datasets used and/or analysed during the current study are available from the corresponding author on reasonable request.

\section{Declarations}

Conflict of interests All authors declare that they have no conflict of interest.

Ethical Approval All procedures performed in studies involving human participants were in accordance with the ethical standards of the institutional and/or national research committee and with the 1964 Helsinki declaration and its later amendments or comparable ethical standards. Data collection was permitted by Local Ethic Committee of University Pecs (use of patient data system of the Clinical Centre of University Pecs) (Permission № PTE/83069/2018).

Consent to Participate The ethics committee of University Pecs agree to waive the consent to participate.

Open Access This article is licensed under a Creative Commons Attribution 4.0 International License, which permits use, sharing, adaptation, distribution and reproduction in any medium or format, as long as you give appropriate credit to the original author(s) and the source, provide a link to the Creative Commons licence, and indicate if changes were made. The images or other third party material in this article are included in the article's Creative Commons licence, unless indicated otherwise in a credit line to the material. If material is not included in 
the article's Creative Commons licence and your intended use is not permitted by statutory regulation or exceeds the permitted use, you will need to obtain permission directly from the copyright holder. To view a copy of this licence, visit http://creativecommons.org/licenses/by/4.0/.

\section{References}

Bardosi S, Bardosi A, Nagy Z, Reglodi D (2016) Expression of PACAP and PAC1 receptor in normal human thyroid gland and in thyroid papillary carcinoma. J Mol Neurosci 60(2):171-178. https://doi. org/10.1007/s12031-016-0823-7

Barlow J, Solomon TPJ, Affourtit C (2018) Pro-inflammatory cytokines attenuate glucose-stimulated insulin secretion from INS-1E insulinoma cells by restricting mitochondrial pyruvate oxidation capacity-novel mechanistic insight from real-time analysis of oxidative phosphorylation. PLoS ONE 13(6):e0199505. https:// doi.org/10.1371/journal.pone.0199505

Bocchini M, Nicolini F, Severi S, Bongiovanni A, Ibrahim T, Simonetti G, Grassi I, Mazza M (2020) Biomarkers for pancreatic neuroendocrine neoplasms (PanNENs) management-an updated review. Front Oncol 10:831. https://doi.org/10.3389/fonc.2020.00831

Borboni P, Porzio O, Pierucci D, Cicconi S, Magnaterra R, Federici M, Sesti G, Lauro D, D’Agata V, Cavallaro S, Marlier LN (1999) Molecular and functional characterization of pituitary adenylate cyclase-activating polypeptide (PACAP-38)/vasoactive intestinal polypeptide receptors in pancreatic $\beta$-cells and effects of PACAP38 on components of the insulin secretory system. Endocrinology 140(12):5530-5537. https://doi.org/10.1210/endo.140.12.7208

Boronkai A, Brubel R, Racz B, Tamas A, Kiss P, Horvath G, Lubics A, Szigeti A, Sz B, Toth G, Lakatos A, Reglodi D (2009) Effects of pituitary adenylate cyclase activating polypeptide on the survival and signal transduction pathways in human choriocarcinoma cells. Ann N Y Acad Sci 1163:353-357. https://doi.org/ 10.1111/j.1749-6632.2008.03630.x

Burns WR, Edil BH (2012) Neuroendocrine pancreatic tumors: guidelines for management and update. Curr Treat Options Oncol 13(1):24-34. https://doi.org/10.1007/s11864-011-0172-2

Calvert PA, Heck PM, Edwards AV (1998) Autonomic control of submandibular protein secretion in the anaesthetized calf. Exp Physiol 83(4):545-556. https://doi.org/10.1113/expphysiol.1998. sp004137

Chen C, Notkins AL, Lan MS (2019) Insulinoma-associated-1: from neuroendocrine tumor marker to cancer therapeutics. Mol Cancer Res 17(8):1597-1604. https://doi.org/10.1158/1541-7786. MCR-19-0286

Czegledi L, Tamas A, Borzsei R, Bagoly T, Kiss P, Horvath G, Brubel R, Nemeth J, Szalontai B, Szabadfi K, Javor A, Reglodi D, Helyes ZS (2011) Presence of pituitary adenylate cyclase-activating polypeptide (PACAP) in the plasma and milk of ruminant animals. Gen Comp Endocrinol 172(1):115-119. https://doi.org/ 10.1016/j.ygcen.2010.12.012

Elsas T, Uddman R, Sundler F (1996) Pituitary adenylate cyclaseactivating peptide-immunoreactive nerve fibers in the cat eye. Graefes Arch Clin Exp Ophthalmol 234(9):573-580. https://doi. org/10.1007/BF00448802

Farini D, Puglianiello A, Mammi C, Siracusa G, Moretti C (2003) Dual effect of pituitary adenylate cyclase activating polypeptide on prostate tumour LNCaP cells: short- and long-term exposure affect proliferation and neuroendocrine differentiation. Endocrinology 144(4):1631-1643. https://doi.org/10.1210/en. 2002-221009

Ferencz S, Reglodi D, Kaszas B, Bardosi A, Toth D, Zs V, Vicena V, Karadi O, Kelemen D (2019) PACAP and PAC1 receptor expression in pancreatic ductal carcinoma. Oncol Lett 18(6):5725-5730. https://doi.org/10.3892/ol.2019.10971

Fridolf T, Sundler F, Ahrén B (1992) Pituitary adenylate cycylaseactivating polypeptide (PACAP-27): occurence in rodent pacreas and effect on insulin and glucagon secretion in the mouse. Cell Tissue Res 269:275-279. https://doi.org/10.1007/BF00319618

Fulop BD, Sandor B, Szentleleky E, Karanyicz E, Reglodi D, Gaszner B, Zakany R, Hashimoto H, Juhasz T, Tamas A (2019) Altered notch signaling in developing molar teeth of pituitary adenylate cyclase-activating polypeptide (PACAP)-deficient mice. J Mol Neurosci 68(3):377-388. https://doi.org/10.1007/ s12031-018-1146-7

Gaál V, Márk L, Kiss P, Kustos I, Tamás A, Kocsis B, Lubics A, Németh V, Németh A, Lujber L, Pytel J, Toth G, Reglodi D (2008) Investigation of the effects of PACAP on the composition of tear and endolymph proteins. J Mol Neurosci 36(1-3):321329. https://doi.org/10.1007/s12031-008-9067-5

Gill GV, Rauf O, MacFarlane IA (1997) Diazoxide treatment for insulinoma: a national UK survey. Postgrad Med J 73:640-641. https://doi.org/10.1136/pgmj.73.864.640

Girard BM, Campbell SE, Beca KI, Perkins M, Hsiang H, May V, Vizzard MA (2020) Intrabladder PAC1 receptor antagonist, PACAP(6-38), reduces urinary bladder frequency and pelvic sensitivity in mice exposed to repeated variate stress (RVS). J Mol Neurosci. https://doi.org/10.1007/s12031-020-01649-x

Goode PN, Farndon JR, Anderson J, Johnston IDA, Morte JA (1986) Diazoxide in the management of patients with insulinoma. World J Surg 10:586-592. https://doi.org/10.1007/BF01655532

Gress T, Muller-Pillasch F, Elsässer H-P, Bachem M, Ferrarra C, Weidenbach H, Lerch M, Adler G (1994a) Enhancement of transforming growth factor PI expression in the rat pancreas during regeneration from caerulein-induced pancreatitis. Eur J Clin Investig 24(10):679-685. https://doi.org/10.1111/j.1365-2362. 1994.tb01060.x

Gress TM, Müller-Pillasch F, Lerch MM, Friess H, Büchler M, Beger HG, Adler G (1994b) Balance of expression of genes coding for extracellular matrix proteins and extracellular matrix degrading proteases in chronic pancreatitis. Z Gastroenterol 32(4):221-225

Hamagami K, Sakurai Y, Shintani N, Higuchi N, Ikeda K, Hashimoto H, Suzuki A, Kiyama H, Baba A (2009) Over-expression of pancreatic pituitary adenylate cyclase-activating polypeptide (PACAP) aggravates cerulein-induced acute pancreatitis in mice. J Pharmacol Sci 110(4):451-458. https://doi.org/10.1254/jphs. 09119fp

Hessenius C, Bäder M, Meinhold H, Böhmig M, Faiss S, Reubi JC, Wiedenmann B (2000) Vasoactive intestinal peptide receptor scintigraphy in patients with pancreatic adenocarcinomas or neuroendocrine tumours. Eur J Nucl Med 27(11):1684-1693. https://doi.org/10.1007/s002590000325

Hirabayashi T, Nakamachi T, Shioda SJ (2018) Discovery of PACAP and its receptors in the brain. J Headache Pain 19(1):28. https:// doi.org/10.1186/s10194-018-0855-1

Inoue H, Shintani N, Sakurai Y, Higashi S, Hayata-Takano A, Baba A, Hashimoto H (2013) PACAP inhibits $\beta$-cell mass expansion in a mouse model of type II diabetes: persistent suppressive effect on islet density. Front Endocrinol (Lausanne) 4:27. https://doi. org/10.3389/fendo.2013.00027

Inoue M, Harada K, Matsuoka H (2020) Mechanisms for pituitary adenylate cyclase-activating polypeptide-induced increase in excitability in guinea-pig and mouse adrenal medullary cells. Eur J Pharmacol 872:172956. https://doi.org/10.1016/j.ejphar. 2020.172956

Juhász T, Matta C, Katona É, Somogyi C, Takács R, Hajdú T, Helgadottir SL, Fodor J, Csernoch L, Tóth G, Bakó É, Reglődi D, Tamás A, Zákány R (2014) Pituitary adenylate cyclase-activating polypeptide (PACAP) signalling enhances osteogenesis in UMR-106 
cell line. J Mol Neurosci 54(3):555-573. https://doi.org/10.1007/ s12031-014-0389-1

Jung S, Yi L, Jeong D, Kim J, An S, Oh TJ, Kim CH, Kim CJ, Yang Y, Kim KI, Lim J-S, Lee M-S (2011) The role of ADCYAP1, adenylate cyclase activating polypeptide, as a methylation biomarker for the early detection of cervical cancer. Oncol Rep 25:245-252

Kacar AK, Bolkent S (2019) Vitronectin, fibronectin and epidermal growth factor induce proliferation via the JNK and ERK pathways in insulinoma INS-1 cells. Cytotechnology 71(1):209-217. https://doi.org/10.1007/s10616-018-0277-6

Kamaishi H, Endoh T, Suzuki T (2004) Multiple signal pathways coupling VIP and PACAP receptors to calcium channels in hamster submandibular ganglion neurons. Auton Neurosci 111(1):15-26. https://doi.org/10.1016/j.autneu.2004.01.002

Klinteberg KA, Karlsson S, Ahrén B (1996) Signaling mechanisms underlying the insulinotropic effect of pituitary adenylate cyclase-activating polypeptide in HIT-T15 cells. Endocrinology 137:2791-2798. https://doi.org/10.1210/endo.137.7.8770899

Koshimura K, Murakami Y, Mitsushima M, Hori T, Kato Y (1997) Activation of $\mathrm{Na}+$ channels in $\mathrm{GH} 3$ cells and human pituitary adenoma cells by PACAP. Peptides 18(6):877-883. https://doi. org/10.1016/s0196-9781(97)00019-3

Lajko A, Meggyes M, Fulop BD, Gede N, Reglodi D, Szereday L (2018) Comparative analysis of decidual and peripheral immune cells and immune-checkpoint molecules during pregnancy in wild-type and PACAP-deficient mice. Am J Reprod Immunol 80(4):e13035. https://doi.org/10.1111/aji.13035

Le SV, Yamaguchi DJ, McArdle CA, Tachiki K, Pisegna JR, Germano P (2002) PAC1 and PACAP expression, signaling, and effect on the growth of HCT8, human colonic tumour cells. Regul Pept 109(1-3):115-125. https://doi.org/10.1016/s01670115(02)00194-5

Le N, Sund M, Vinci A, on behalf of the GEMS collaborating group of Pancreas 2000 (2016) Prognostic and predictive markers in pancreatic adenocarcinoma. Dig Liver Dis 48:223-230. https:// doi.org/10.1016/j.dld.2015.11.001

Lee JH, Lee JY, Rho SB, Choi JS, Lee DG, An S, Oh T, Choi DC, Lee SH (2014) PACAP inhibits tumour growth and interferes with clusterin in cervical carcinomas. FEBS Lett 588(24):4730-4739. https://doi.org/10.1016/j.febslet.2014. 11.004

Lévy P, Domínguez-Muñoz E, Imrie C, Löhr M, Maisonneuve P (2014) Epidemiology of chronic pancreatitis: burden of the disease and consequences. United Eur Gastroenterol J 2(5):345-354. https:// doi.org/10.1177/2050640614548208

Liu M, Yang X, Bai T, Liu Z, Liu T, Wang Y, Cui L, Liu Y, Zhang Y (2019) PACAP stimulates insulin secretion by PAC1 receptor and ion channels in $\beta$-cells. Cell Signal 61:48-56. https://doi.org/10. 1016/j.cellsig.2019.05.006

Lohrer P, Gloddek J, Hopfner U, Losa M, Uhl E, Pagotto U, Stalla GK, Renner U (2001) Vascular endothelial growth factor production and regulation in rodent and human pituitary tumor cells in vitro. Neuroendocrinology 74(2):95-105. https://doi.org/10. $1159 / 000054675$

Loosen SH, Neumann UP, Trautwein C, Roderburg C, Luedde T (2017) Current and future biomarkers for pancreatic adenocarcinoma. Tumour Biol 39(6):1010428317692231. https://doi.org/10.1177/ 1010428317692231

Luts L, Bergenfelz A, Alumets J, Luts A, Sundler F (1996) VIP- and PACAP-containing nerve fibers in human parathyroid glands and adenomas: comparison of innervation pattern with animal species. Ann N Y Acad Sci 26(805):661-665. https://doi.org/10. 1111/j.1749-6632.1996.tb17537.x

Matoba Y, Nonaka N, Takagi Y, Imamura E, Narukawa M, Nakamachi T, Shioda S, Banks WA, Nakamura M (2016) Pituitary adenylate cyclase-activating polypeptide enhances saliva secretion via direct binding to PACAP receptors of major salivary glands in mice. Anat Rec (Hoboken) 299(9):1293-1299. https://doi.org/ 10.1002/ar.23388

Maton PN (1993) Use of octreotide acetate for control of symptoms in patients with islet cell tumours. World J Surg 17:504-510. https://doi.org/10.1007/BF01655110

Maugeri G, D’Amico AG, Reitano R, Magro G, Cavallaro S, Salomone S, D'Agata V (2016) PACAP and VIP inhibit the invasiveness of glioblastoma cells exposed to hypoxia through the regulation of HIF s and EGFR expression. Front Pharmacol 7:139. https:// doi.org/10.3389/fphar.2016.00139

Maugeri G, D'Amico AG, Rasà DM, Saccone S, Federico C, Cavallaro S, D'Agata V (2018) PACAP and VIP regulate hypoxia-inducible factors in neuroblastoma cells exposed to hypoxia. Neuropeptides 69:84-91. https://doi.org/10.1016/j.npep.2018.04.009

Maugeri G, D'Amico AG, Bucolo C, D'Agata V (2019a) Protective effect of PACAP-38 on retinal pigmented epithelium in an in vitro and in vivo model of diabetic retinopathy through EGFRdependent mechanism. Peptides 119:170108. https://doi.org/10. 1016/j.peptides.2019.170108

Maugeri G, D’Amico AG, Castrogiovanni P, Saccone S, Federico C, Reibaldi M, Russo A, Bonfiglio V, Avitabile T, Longo A, D'Agata V (2019b) PACAP through EGFR transactivation preserves human corneal endothelial integrity. J Cell Biochem 120(6):10097-10105. https://doi.org/10.1002/jcb.28293

Maugeri G, D'Amico AG, Rasà DM, Federico C, Saccone S, Morello G, La Cognata V, Cavallaro S, D’Agata V (2019c) Molecular mechanisms involved in the protective effect of pituitary adenylate cyclase-activating polypeptide in an in vitro model of amyotrophic lateral sclerosis. J Cell Physiol 234:5203-5214. https://doi.org/10.1002/jcp. 27328

Maugeri G, D’Amico AG, Musumeci G, Reglodi D, D’Agata V (2020) Effects of PACAP on Schwann cells: focus on nerve injury. Int J Mol Sci 21(21):8233. https://doi.org/10.3390/ijms21218233

May V, Johnson GC, Hammack SE, Braas KM, Parsons RL (2021) PAC1 receptor internalization and endosomal MEK/ERK activation is essential for PACAP-mediated neuronal excitability. J Mol Neurosci. https://doi.org/10.1007/s12031-021-01821-x

Mehrabi A, Fischer L, Hafezi M, Dirlewanger A, Grenacher L, Diener MK, Fonouni H, Golriz M, Garoussi C, Fard N, Rahbari NN, Werner J, Büchler MW (2014) A systematic review of localization, surgical treatment options, and outcome of insulinoma. Pancreas 43(5):675-686. https://doi.org/10.1097/MPA.00000 00000000110

Michalski CW, Selvaggi F, Bartel M, Mitkus T, Gorbachevski A, Giese T, Di Sebastiano P, Giese NA, Friess H (2008) Altered anti-inflammatory response of mononuclear cells to neuropeptide PACAP is associated with deregulation of NF- $\{$ kappa $\}$ B in chronic pancreatitis. Am J Physiol Gastrointest Liver Physiol 294(1):G50-57. https://doi.org/10.1152/ajpgi.00058.2007

Mirfendereski S, Tobin G, Hakanson R, Ekström J (1997) Pituitary adenylate cyclase activating peptide (PACAP) in salivary glands of the rat: origin, and secretory and vascular effects. Acta Physiol Scand 160(1):15-22. https://doi.org/10.1046/j.1365-201X.1997. 00010.x

Miyata A, Arimura A, Dahl RR, Minamino N, Uehara A, Jiang L, Culler MD, Coy DH (1989) Isolation of a novel 38 residue-hypothalamamic polypeptide which stimulates adenylate cyclase in pituitary cells. Biochem Biophys Res Commun 164(1):567-574. https://doi.org/10.1016/0006-291x(89)91757-9

Miyata A, Jiang L, Dahl RD, Kitada C, Kubo K, Fujino M, Minamino $\mathrm{N}$, Arimura A (1990) Isolation of a neuropeptide corresponding to the N-terminal 27 residues of the pituitary adenylate cyclase activating polypeptide with 38 residues (PACAP38). Biochem Biophys Res Commun 170(2):643-648. https://doi.org/10.1016/ 0006-291x(90)92140-u 
Moody TW, Jensen RT (2016) PACAP and cancer. In: Reglodi D, Tamas A (eds) Pituitary adenylate cyclase activating polypeptide-PACAP. Springer, Cham, pp 795-814

Moody TW, Chan D, Fahrenkrug J, Jensen RT (2003) Neuropeptides as autocrine growth factors in cancer cells. Curr Pharm Des 9(6):495-509. https://doi.org/10.2174/1381612033391621

Moody TW, Nuche-Berenguer B, Jensen RT (2016) Vasoactive intestinal peptide/pituitary adenylate cyclase activating polypeptide, and their receptors and cancer. Curr Opin Endocrinol Diabetes Obes 23:38-47. https://doi.org/10.1097/MED.0000000000 000218

Moody TW, Lee L, Jensen RT (2020) The G protein-coupled receptor PAC1 regulates transactivation of the receptor tyrosine kinase HER3. J Mol Neurosci. https://doi.org/10.1007/ s12031-020-01711-8

Nakamachi T, Ohtaki H, Seki T, Yofu S, Kagami N, Hashimoto H, Shintani N, Baba A, Mark L, Lanekoff I, Kiss P, Farkas J, Reglodi D, Shioda S (2016) PACAP suppresses dry eye signs by stimulating tear secretion. Nat Commun 7:12034. https://doi.org/ 10.1038/ncomms 12034

Nakayama S, Yokote T, Kobayashi K, Hirata Y, Hiraiwa T, Komoto I, Miyakoshi K, Yamakawa Y, Takubo T, Tsuji M, Imamura M, Hanafusa T (2009) VIPoma with expression of both VIP and VPAC1 receptors in a patient with WDHA syndrome. Endocrine 35(2):143-146. https://doi.org/10.1007/ s12020-009-9146-6

Nakamura K, Nakamachi T, Endo K, Ito K, Machida T, Oka T, Hori M, Ishizaka K, Shioda S (2014) Distribution of pituitary adenilate cyclase-activating polypeptide (PACAP) in the human testis and in testicular germ cell tumours. Andrologia 46(5):465-471. https://doi.org/10.1111/and.12102

Ojala J, Tooke K, Hsiang H, Girard BM, May V, Vizzard MA (2019) PACAP/PAC1 expression and function in micturition pathways. J Mol Neurosci 68:357-367. https://doi.org/10.1007/ s12031-018-1170-7

Oka H, Jin L, Kulig E, Scheithauer BW, Lloyd RV (1999) Pituitary adenylate cyclase-activating polypeptide inhibits transforming growth factor-b1-induced apoptosis in a human pituitary adenoma cell line. Am J Pathol 155(6):1893-1900. https://doi.org/ 10.1016/s0002-9440(10)65509-5

Okabayashi T, Shima Y, Sumiyoshi T, Kozuki A, Ito S, Ogawa Y, Kobayashi M, Hanazaki K (2013) Diagnosis and management of insulinoma. World J Gastroenterol 19(6):829-837. https://doi. org/10.3748/wjg.v19.i6.829

Parsons RL, May V (2019) PACAP-induced PAC1 receptor internalization and recruitment of endosomal signaling regulate cardiac neuron excitability. J Mol Neurosci 68:340-347. https://doi.org/ 10.1007/s12031-018-1127-x

Pedersen AM, Dissing S, Fahrenkrug J, Hannibal J, Reibel J, Nauntofte B (2000) Innervation pattern and $\mathrm{Ca} 2+$ signalling in labial salivary glands of healthy individuals and patients with primary Sjögren's syndrome (pSS). J Oral Pathol Med 29(3):97-109. https://doi.org/10.1034/j.1600-0714.2000.290301.x

Pohóczky K, Tamás A, Reglődi D, Kemény Á, Zs H, Czeglédi L (2020) Pituitary adenylate cyclase activating polypeptide concentrations in the sheep mammary gland, milk, and in the lamb blood plasma after suckling. Physiol Int 107(1):92-105. https://doi.org/10. 1556/2060.2020.00006

Qiao X-W, Qiu L, Chen Y-J, Meng C-T, Sun Z, Bai C-M, Zhao D-C, Zhang T-P, Zhao Y-P, Song Y-L, Wang Y-H, Chen J, Lu C-M (2014) Chromogranin A is a reliable serum diagnostic biomarker for pancreatic neuroendocrine tumors but not for insulinomas. BMC Endocr Disord 14:64. https://doi.org/10.1186/ 1472-6823-14-64

Raderer M, Kurtaran A, Yang Q, Meghdadi S, Vorbeck F, Hejna M, Angelberger P, Kornek G, Pidlich J, Scheithauer W, Virgolini I
(1998) Iodine-123-vasoactive intestinal peptide receptor scanning in patients with pancreatic cancer. J Nucl Med 39(9):1570-1575

Raimondi S, Lowenfels AB, Morselli-Labate AM, Maisonneuve P, Pezzilli R (2010) Pancreatic cancer in chronic pancreatitis; aetiology, incidence, and early detection. Best Pract Res Clin Gastroenterol 24(3):349-358. https://doi.org/10.1016/j.bpg.2010. 02.007

Reglodi D, Tamas A (2016) Pituitary adenylate cyclase activating polypeptide-Current topics in neurotoxicity. Springer, Cham, pp $1-840$

Reglodi D, Illes A, Opper B, Schafer E, Tamas A, Horvath G (2018) Presence and effects of pituitary adenylate cyclase activating polypeptide under physiological and pathological conditions in the stomach. Front Endocrinol (Lausanne) 9:90. https://doi.org/ 10.3389/fendo.2018.00090

Reubi JC, Läderach U, Waser B, Gebbers JO, Robberecht P, Laissue JA (2000) Vasoactive intestinal peptide/pituitary adenylate cyclaseactivating peptide receptor subtypes in human tumours and their tissues of origin. Cancer Res 60(11):3105-3112

Rytel L, Wojtkiewicz J, Snarska A, Mikołajczyk A (2020) Changes in the neurochemical characterization of enteric neurons in the porcine duodenum after administration of low-dose Salmonella Enteritidis lipopolysaccharides. J Mol Neurosci. https://doi.org/ 10.1007/s12031-019-01473-y

Sakurai Y, Shintani N, Hayata A, Hashimoto H, Baba A (2011) Trophic effects of PACAP on pancreatic islets: a mini-review. J Mol Neurosci 43(1):3-7. https://doi.org/10.1007/s12031-010-9424-z

Saloman JL, Singhi AD, Hartman DJ, Normolle DP, Albers KM, Davis BM (2018) Systemic depletion of nerve growth factor inhibits disease progression in a genetically engineered model of pancreatic ductal adenocarcinoma. Pancreas 47(7):856-863. https://doi. org/10.1097/MPA.0000000000001090

Sandor B, Fintor K, Reglodi D, Fulop DB, Helyes Z, Szanto I, Nagy $\mathrm{P}$, Hashimoto H, Tamas A (2016) Structural and morphometric comparison of lower incisors in PACAP-deficient and wild-type mice. J Mol Neurosci 59(2):300-308. https://doi.org/10.1007/ s12031-016-0765-0

Sarszegi Z, Szabo D, Gaszner B, Konyi A, Reglodi D, Nemeth J, Lelesz B, Polgar B, Jungling A, Tamas A (2019) Examination of pituitary adenylate cyclase-activating polypeptide (PACAP) as a potential biomarker in heart failure patients. J Mol Neurosci 68:368-376. https://doi.org/10.1007/s12031-017-1025-7

Sayo Y, Hosokawa H, Imachi H, Murao K, Sato M, Wong NCW, Ishida T, Takahara J (2000) Transforming growth factor b induction of insulin gene expression is mediated by pancreatic and duodenal homeobox gene-1 in rat insulinoma cells. Eur J Biochem 267(4):971-978. https://doi.org/10.1046/j.1432-1327.2000. 01080.x

Schäfer H, Zheng J, Gundlach F, Günther R, Schmidt WE (1996) PACAP stimulates transcription of c-Fos and c-Jun and activates the AP-1 transcription factor in rat pancreatic carcinoma cells. Biochem Biophys Res Commun 221(1):111-116. https://doi.org/ 10.1006/bbrc. 1996.0554

Schmidt WE, Seebeck J, Höcker M, Schwarzhoff R, Schäfer H, Fornefeld H, Morys-Wortmann C, Fölsch UR, Creutzfeldt W (1993) PACAP and VIP stimulate enzyme secretion in rat pancreatic acini via interaction with VIP/PACAP-2 receptors: additive augmentation of CCK/carbachol-induced enzyme release. Pancreas 8(4):476-487. https://doi.org/10.1097/00006676-19930 7000-00012

Schulz S, Röcken C, Mawrin C, Weise W, Höllt V, Schulz S (2004) Immunocytochemical identification of VPAC1, VPAC2, and PAC1 receptors in normal and neoplastic human tissues with subtype-specific antibodies. Clin Cancer Res 10(24):8235-8242. https://doi.org/10.1158/1078-0432.CCR-04-0939 
Schulz S, Mann A, Novakhov B, Piggins HD, Lupp A (2015) VPAC2 receptor expression in human normal and neoplastic tissues: Evaluation of the novel MAB SP235. Endocr Connect 4(1):1826. https://doi.org/10.1530/EC-14-0051

Shan W, Lu S, Ou B, Feng J, Wang Z, Li H, Lu X, Yi M (2021) PACAP ameliorates the fertility of obese mice through PAC1/PKA/ ERK/Nrf2 signal axis. J Endocrinol. https://doi.org/10.1530/ JOE-20-0316

Shin JJ, Gorden P, Libutti SK (2010) Insulinoma: pathophysiology, localization and management. Future Oncol 6(2):229-237. https://doi.org/10.2217/fon.09.165

Skakkebaek M, Hannibal J, Fahrenkrug J (1999) Pituitary adenylate cyclase activating polypeptide (PACAP) in the rat mammary gland. Cell Tissue Res 298(1):153-159. https://doi.org/10.1007/ s004419900086

Szanto Z, Sarszegi Z, Reglodi D, Nemeth J, Szabadfi K, Kiss P, Varga A, Banki E, Csanaky K, Gaszner B, Pinter O, Zs S, Tamas A (2012) PACAP immunoreactivity in human malignant tumour samples and cardiac diseases. J Mol Neurosci 48(3):667-673. https://doi.org/10.1007/s12031-012-9815-4

Tamas A, Javorhazy A, Reglodi D, Sarlos DP, Banyai D, Semjen D, Nemeth J, Lelesz B, Fulop DB, Szanto Z (2016) Examination of PACAP-like immunoreactivity in urogenital tumour samples. J Mol Neurosci 59(2):177-183. https://doi.org/10.1007/ s12031-015-0652-0

Tang C, Biemond I, Offerhaus GJ, Verspaget W, Lamers CB (1997) Expression of receptors for gut peptides in human pancreatic adenocarcinoma and tumour-free pancreas. Br J Cancer 75(10):1467-1473. https://doi.org/10.1038/bjc.1997.251

Thouënnon E, Pierre A, Yon L, Anouar Y (2010) Expression of trophic peptides and their receptors in chromaffin cells and pheochromocytoma. Cell Mol Neurobiol 30(8):1383-1389. https://doi.org/10. 1007/s10571-010-9594-9

Tobin G, Asztély A, Edwards AV, Ekström J, Hakanson R, Sundler F (1995) Presence and effects of pituitary adenylate cyclase activating peptide in the submandibular gland of the ferret. Neuroscience 66(1):227-235. https://doi.org/10.1016/0306-4522(94) 00622-c

Toth D, Szabo E, Tamas A, Juhasz T, Horvath G, Fabian E, Opper B, Szabo D, Maugeri G, D'Amico AG, D'Agata V, Vicena V, Reglodi D (2020) Protective effects of PACAP in peripheral organs. Front Endocrinol (Lausanne) 11(377):2020. https://doi.org/10. 3389/fendo.2020.00377

Vaudry D, Falluel-Morel A, Bourgault S, Basille M, Burel D, Wurtz O, Fournier A, Chow BK, Hashimoto H, Galas L, Vaudry H (2009) Pituitary adenylate cyclase-activating polypeptide and its receptors: 20 years after the discovery. Pharmacol Rev 61(3):283-357. https://doi.org/10.1124/pr.109.001370

Vidaltamayo R, Mery CM, Angeles-Angeles A, Robles-Díaz G, Hiriart M (2003) Expression of nerve growth factor in human pancreatic beta cells. Growth Factors 21(3-4):103-107. https://doi.org/10. 1080/08977190310001629566

Whipple O, Frantz VK (1935) Adenoma of islet cells with hyperinsulinism: a review. Ann Surg 101(6):1299-1335. https://doi.org/ 10.1097/00000658-193506000-00001

Wiese M, Gärtner S, Doller J, Tran TQ, Frost F, Bannert K, Jaster R, Berlin P, Valentini L, Meyer F, Metges CC, Lamprecht G, Lerch MM, Aghdassi AA (2020) Nutritional management of chronic pancreatitis: a systematic review and meta-analysis of randomized controlled trials. J Gastroenterol Hepatol. https:// doi.org/10.1111/jgh.15230

Winzell MS, Ahrén B (2007) Role of VIP and PACAP in islet function. Peptides 28(9):1805-1813. https://doi.org/10.1016/j.pepti des.2007.04.024

Wojcieszak J, Zawilska JB (2014) PACAP38 and PACAP6-38 exert cytotoxic activity against human retinoblastoma Y79 cells. J Mol Neurosci 54(3):463-468. https://doi.org/10.1007/ s12031-014-0248-0

Xu L, Haoyong Y, Jun Y, Lianxi L, Jian Z, Ming L, Qing L, Haibing C, Fang L, Yuqian B, Han J, Jia W (2017) Decreased levels of fibroblast growth factor 21 are correlated with improved hypoglycemia in patients with insulinoma. Sci Rep 22(7):43123. https:// doi.org/10.1038/srep43123

Xu Z, Ohtaki H, Watanabe J, Miyamoto K, Murai N, Sasaki S, Matsumoto M, Hashimoto H, Hiraizumi Y, Numazawa S, Shioda S (2016) Pituitary adenylate cyclase-activating polypeptide (PACAP) contributes to the proliferation of hematopoietic progenitor cells in murine bone marrow via PACAP-specific receptor. Sci Rep 6:22373. https://doi.org/10.1038/srep22373

Yada T, Sakurada M, Ihida K, Nakata M, Murata F, Arimura A, Kikuchi M (1994) Pituitary adenylate cyclase activating polypeptide is an extraordinarily potent intra-pancreatic regulator of insulin secretion from islet beta-cells. J Biol Chem 269:1290-1293

Yamaoka T, Ohba M, Ohmori T (2017) Molecular-targeted therapies for epidermal growth factor receptor and its resistance mechanisms. Int J Mol Sci 18(11):2420. https://doi.org/10.3390/ijms1 8112420

Zibara K, Zeidan A, Mallah K, Kassem N, Awad A, Mazurier F, Badran B, El-Zein N (2018) Signaling pathways activated by PACAP in MCF-7 breast cancer cells. Cell Signal 50:37-47. https://doi.org/10.1016/j.cellsig.2018.06.009

Publisher's Note Springer Nature remains neutral with regard to jurisdictional claims in published maps and institutional affiliations. 